\title{
Drought Stress Syndrome in Wheat Is Provoked by Ethylene Evolution Imbalance and Reversed by Rewatering, Aminoethoxyvinylglycine, or Sodium Benzoate
}

\author{
J. Beltrano,* M. G. Ronco, and E. R. Montaldi \\ Instituto de Fisiología Vegetal, Fac. de Ciencias Agrarias y Forestales, Fac. de Ciencias Naturales y Museo, UNLP, CC 327, \\ 1900 La Plata, Argentina
}

Received June 11, 1998; accepted March 10, 1999

\begin{abstract}
In this work we present evidence that the drought stress syndrome in the flag leaves and ears of wheat plants, provoked by the production of ethylene (shortening the grain filling period and lowering the grain weight) is reversed by the application of a free radical scavenger, sodium benzoate or the ethylene synthesis inhibitor, aminoethoxyvinylglycine. Rehydration by watering also attenuated the detrimental effect of the water deficit. Consequently, the grain filling period was longer, the grain weight increased, and the total protein content was higher than that in plants watered regularly.
\end{abstract}

Key Words. Ethylene-Drought-RewateringScavengers-Water stress-Wheat

Stress provoked by drought is one of the most important factors limiting crop yields worldwide (Jones and Corlett 1992). The intensity of the response depends upon the severity and the duration of the stress and the plant developmental stage (Bray 1993).

The most notorious symptoms of water deficit are reduced growth, a decrease in $\mathrm{CO}_{2}$ efficiency by stomatal closure, and early senescence of older leaves (Bradford and Hsiao 1982, Kramer 1983). Nevertheless, primary biochemical reactions that affect the metabolism of the whole plant are complex. It has been reported that alterations of photosynthetic membranes and a decrease of the ribosomes and polysomes are the earlier changes provoked by water deficit (Cuello and Lahora 1993, Hendry

\footnotetext{
Abbreviations: AVG, aminoethoxyvinylglycine; Benz, sodium benzoate; ET, ethephon; FW, fresh weight; TGW, thousand-grain weight; $\Psi_{\mathrm{W}}$, water potential.

*Author for correspondence.
}

et al. 1987, Thimann 1980). It is known that when leaves are subjected to water stress, the chlorophyll content declines rapidly, and it is more rapid with the stress severity (Baisak et al. 1994). The leaf senescence is accelerated, and finally the plant dies (Bradford and Hsiao 1982, Levitt 1980, Turner 1986). This phenomenon in wheat, if it occurs at a later growth stage, causes the yellowing of flag leaf and a rapid maturity of ears and grains (Beltrano et al. 1994).

Water stress also causes the disruption of membrane properties such as selective permeability (leakage of solutes), fluidity, and microviscosity (Navarri-Izzo et al. 1993). Others authors also have reported changes in the lipid/protein ratio of the membrane and in enzyme structure, as in various proteases and lipases (Caldwell and Whitman 1987, Noodén and Guiamet 1996). It has been postulated that the breakdown of the lipid/protein configuration of the membrane is promoted by the lipid peroxidation caused by free radicals (Paulin et al. 1986). Under well watered conditions, plants are protected against the deleterious effects of oxygen metabolism by antioxidant complex systems (Elstner 1982, Smirnoff 1993, Winston 1990). Nevertheless, under severe water stress, these reactive oxygen species are generated in excess (Navarri-Izzo et al. 1993, Quartacci and NavarriIzzo 1992, Senaratna et al. 1985).

In previous work, we found that in wheat flag leaves, water deficit increased not only the free radical levels but also those of antioxidant scavengers (Beltrano et al. 1997) as a means of self-preservation.

In this context, the aim of this work was to examine whether the increase of free radicals induced by water stress and the parallel augmentation of ethylene synthesis, can be reversed by a free radical scavenger and/or by an ethylene inhibitor. Another goal was to examine the response of wheat plants to the impact of rewatering after a period of water stress. Further, the effect of the above treatments on grain duration and on the final weight and 
protein content was also evaluated. Because both free radicals and ethylene are expected to shorten the grain filling period under drought, we assumed that treatments with substances that remove oxidative species or inhibit ethylene biosynthesis as well as rewatering should attenuate the negative effects of water deficit on ear growth and on grain weight.

\section{Materials and Methods}

\section{Plant Growth}

Wheat (Triticum aestivum L. cv. Buck Poncho) caryopses were sown (one seedling/pot) in 10-liter plastic pots filled with a greenhouse soil, a mixture of three parts of clay loam and one part of sand. The soil was very homogeneous. Plants were watered daily and fertilized twice a week with half-strength Hoagland's solution (Hoagland and Arnon 1950). Neither symptoms of mineral deficiencies nor pest attacks were observed. The plants were grown for 6 months in a greenhouse from sowing until maturity and harvest (from July to December 1994). The maximum photosynthetic photon flux density at the plant top was 1,300 $\mu \mathrm{mol} \mathrm{m} \mathrm{m}^{-2} \mathrm{~s}^{-1}$ in July and 2,200 $\mu \mathrm{mol} \mathrm{m} \mathrm{m}^{-2} \mathrm{~s}^{-1}$ in December. The photoperiod was that of the locality (La Plata, 34' S.L. 54' W.L.).

Fresh air was supplied continuously to the greenhouse to prevent the accumulation of ethylene and $\mathrm{CO}_{2}$ as described by Beltrano et al. (1994).

\section{Water Treatments}

Plants were subjected to the following treatments.

Control $(C)$. Plants were watered to maintain the flag leaf with a midday water potential $\left(\Psi_{\mathrm{W}}\right)$ no lower than $-0.2 \mathrm{MPa}$

Water Stress (St). Plants were subjected to stress for 1 week by withholding watering (flag leaf reached $\Psi_{\mathrm{w}}-1.9 \mathrm{MPa}$ ).

Stress plus Rewatering $(R w)$. Plants were exposed to water stress for 1 week $\left(\Psi_{\mathrm{W}}-1.9 \mathrm{MPa}\right)$ and then watered until the flag leaves reached control values.

The measurement started in stressed plants when they had attained a $\Psi_{\mathrm{W}}$ as low as $-1.9 \mathrm{MPa}$; in rewatering plants it began when the $\Psi_{\mathrm{W}}$ reached $-0.2 \mathrm{MPa}$, approximately $24 \mathrm{~h}$ after watering. Treatments were applied at different stages of grain filling: late milk, soft dough, hard dough 1, and hard dough 3 (Zadocks et al. 1974).

\section{Spraying Treatments}

From anthesis to hard dough 1 stages, lots of 15 plants were sprayed with each of the following solutions: $50 \mu \mathrm{M} \mathrm{AVG}$ solution, $1 \mathrm{~mm}$ Benz solution, and $50 \mathrm{~mm}$ ET solution (Beltrano et al. 1994). They were used as an inhibitor of ethylene synthesis, a free radical scavenger, and an exogenous source of ethylene, respectively. Controls were sprayed with distilled water. The substances were sprayed on ears (in the top of the plants) once a week on the different treatments until the dropping point.
After $72 \mathrm{~h}$, samples were obtained for analysis. Concentrations applied produced neither apparent toxicity nor less growth or localized necrosis.

\section{Measurement}

Water potential $\left(\Psi_{\mathrm{W}}\right)$ was measured on six random flag leaves/ treatment at the different stages by using a pressure chamber (Sholander et al. 1965).

Ethylene evolution by flag leaves and ears was determined as described in Beltrano et al. (1994).

Leakage of solutes was measured in five flag leaf discs $(1.1-\mathrm{cm}$ diameter each) and in $500 \mathrm{mg}$ of awns plus glumes/treatment at two stages after anthesis (late milk and hard dough 1). The conductivity was measured with a DIGICOND IV conductimeter (Luftman Co.) and expressed as $\mu \mathrm{S} \mathrm{m}^{-2} \mathrm{~h}^{-1}$ (flag leaves) or $\mu \mathrm{S} \mathrm{mg}^{-1} \mathrm{~h}^{-1}$ (ears).

The degradation of chlorophyll was used as an index of senescence, and it was determined according to Zschiele and Comar (1941) in five flag leaf discs (1.1-cm diameter each) or in 500-mg glumes plus awns. Samples were taken at the same stages as above and in all treatments. The chlorophyll content was expressed as the percentage of water control (100\%).

For each treatment, started at the soft dough stage, about $1 \mathrm{~g}$ of grain was sampled at maturity, and the total protein content $(5.7 \times \% \mathrm{~N}$ in dry matter) was determined by micro-Kjeldahl. In addition, the thousandgrain weight (TGW) was also determined for each treatment.

Data were analyzed statistically by analysis of variance $(p=0.05)$.

\section{Results}

\section{Ethylene Evolution by Flag Leaves and Ears}

The flag leaves and ears of all of the treatments produced ethylene during the different stages of the grain filling (Table 1), as was found previously (Beltrano et al. 1994).

$\mathrm{C}$ as well as St plants emitted ethylene during all grain filling periods (Table 1). The level of ethylene produced by flag leaves and ears of St plants was well above the control in late milk, soft dough, and hard dough 1 stages. The effect was more evident in flag leaves than in ears.

The flag leaves and ears of Rw plants diminished significantly in the late milk stage, ethylene production; in the other stages it was negligible.

ET increased ethylene production significantly in flag leaves and ears in C and St plants as well as in Rw plants during the entire grain filling period.

The amount of ethylene produced from flag leaves and ears decreased substantially below the water-C in all treatments soon after the first application of AVG or Benz. This effect was evident as well in flag leaves as in ears, and it was observed during the entire grain filling period (Table 1).

\section{Leakage of Solutes from Flag Leaves and Ears}

The loss of solutes from flag leaf discs of AVG-C and Benz-C plants was not significantly different from that of water-C. In contrast, ET-C showed a great difference 
Table 1. Effect of $50 \mu \mathrm{M} \mathrm{AVG,} 1 \mathrm{~mm}$ Benz, and $50 \mathrm{~mm}$ ET, sprayed at postanthesis, on the evolution of ethylene (nL g $\left.\mathrm{g}^{-1} \mathrm{FW} \mathrm{h}^{-1}\right)$ from flag leaves and ears at various grain developmental stages of wheat. Data within columns accompanied by the same letter are not significantly different at $P=$ 0.05 .

\begin{tabular}{|c|c|c|c|c|c|c|c|c|}
\hline \multirow[b]{3}{*}{ Treatment } & \multicolumn{8}{|l|}{ Stage } \\
\hline & \multicolumn{2}{|c|}{ Late milk } & \multicolumn{2}{|c|}{ Soft dough } & \multicolumn{2}{|c|}{ Hard dough 1} & \multicolumn{2}{|c|}{ Hard dough 3} \\
\hline & Leaves & Ears & Leaves & Ears & Leaves & Ears & Leaves & Ears \\
\hline \multicolumn{9}{|l|}{ Water } \\
\hline $\mathrm{C}$ & $0.24 b$ & $0.36 b$ & $0.12 a$ & $0.13 a$ & $0.23 a$ & $0.05 a$ & $2.33 c$ & $1.13 b$ \\
\hline St & $0.67 c$ & $0.45 c$ & $0.73 b$ & $0.37 b$ & $1.13 b$ & $0.32 b$ & $1.35 b$ & $0.23 a$ \\
\hline Rw & $0.10 a$ & $0.08 a$ & & & & & & \\
\hline \multicolumn{9}{|l|}{ AVG } \\
\hline $\mathrm{C}$ & $0.08 a$ & $0.06 a$ & $0.05 a$ & $0.03 a$ & $0.04 a$ & $0.04 a$ & $0.34 a$ & $0.06 a$ \\
\hline St & $0.02 a$ & $0.29 a$ & $0.62 b$ & $0.31 a$ & $0.06 a$ & $0.01 a$ & $0.63 a$ & $0.06 a$ \\
\hline $\mathrm{Rw}$ & $0.04 a$ & $0.02 a$ & & & & & & \\
\hline \multicolumn{9}{|l|}{ Benz } \\
\hline $\mathrm{C}$ & $0.11 a$ & $0.03 a$ & $0.10 a$ & $0.11 a$ & $0.07 a$ & $0.03 a$ & $0.39 a$ & $0.06 a$ \\
\hline St & $0.09 a$ & $0.05 a$ & $0.54 b$ & $0.10 a$ & $0.05 a$ & $0.11 a$ & $1.44 b$ & $0.07 a$ \\
\hline $\mathrm{Rw}$ & $0.04 a$ & $0.02 a$ & & & & & & \\
\hline \multicolumn{9}{|l|}{ ET } \\
\hline $\mathrm{C}$ & $15.03 d$ & $13.44 d$ & $3.36 c$ & $25.30 b$ & $2.80 c$ & $14.90 c$ & $3.21 e$ & $13.29 c$ \\
\hline St & $15.20 d$ & $16.78 d$ & $5.54 d$ & $67.81 c$ & $2.03 c$ & $10.62 c$ & $8.97 d$ & $31.15 d$ \\
\hline $\mathrm{Rw}$ & $19.41 e$ & $20.00 e$ & & & & & & \\
\hline
\end{tabular}

from water-C. Leakage of electrolytes from ears sprayed with AVG or Benz was lower than that in those treated with ET or water (Table 2).

The leakage of solutes from the flag leaves and ears was increased significantly by water stress, irrespective of the spraying treatment.

The cellular membranes of ears of St or C plants, sprayed with ET at the hard dough 1 stage, probably lost the selective control of permeability. Consequently, the loss of solutes in this treatment was the highest found in these experiments (Table 2).

\section{Chlorophyll Determinations in Flag Leaves and Ears (Glumes and Awns)}

In C plants, the chlorophyll content of flag leaves, at the late milk stage, was not affected by treatment with ET, AVG, or Benz (Fig. 1). Plants sprayed with AVG or Benz and subjected to St maintained their chlorophyll content, whereas that of ET-St decreased significantly. At the hard dough 1 stage, the chlorophyll content in flag leaves was reduced by ET treatment, whereas AVG and Benz retained more chlorophyll in $\mathrm{C}$ as well as in $\mathrm{St}$ plants.

The ears (glumes and awns) of AVG-C and Benz-C, for the two grain filling stages, retained much more chlorophyll than water-C or ET-C (Fig. 2); at the late milk stage, the differences were more evident. AVG-St and Benz-St plants also maintained more chlorophyll than water-C.
Table 2. Effect of $50 \mu \mathrm{M} \mathrm{AVG}, 1 \mathrm{~mm}$ Benz, and $50 \mathrm{~mm}$ ET, sprayed at postanthesis, on flag leaves $\left(\mu \mathrm{S} \mathrm{cm}{ }^{-1} \mathrm{~h}^{-1}\right.$ ) and ears $\mu \mathrm{Sg}^{-1} \mathrm{~h}^{-1}$ ) conductivity at late milk and hard dough 1 stages of wheat plants. Data within columns accompanied by the same letter are not significantly different at $p=0.05$.

\begin{tabular}{|c|c|c|c|c|}
\hline \multirow[b]{3}{*}{ Treatment } & \multicolumn{4}{|l|}{ Stage } \\
\hline & \multicolumn{2}{|c|}{ Late milk } & \multicolumn{2}{|c|}{ Hard dough 1} \\
\hline & Leaves & Ears & Leaves & Ears \\
\hline \multicolumn{5}{|l|}{ Water } \\
\hline $\mathrm{C}$ & $41.5 a$ & $58.2 b$ & $39.2 a$ & $74.5 b$ \\
\hline St & $56.8 b$ & $73.8 e$ & $82.5 c$ & $117.4 e$ \\
\hline \multicolumn{5}{|l|}{ AVG } \\
\hline $\mathrm{C}$ & $42.4 a$ & $33.1 a$ & $40.9 a$ & $54.3 a$ \\
\hline St & $51.6 b$ & $61.2 c$ & $63.2 b$ & $95.6 c$ \\
\hline \multicolumn{5}{|l|}{ Benz } \\
\hline $\mathrm{C}$ & $45.8 a$ & $44.3 a$ & $47.3 a$ & $71.4 b$ \\
\hline St & $57.1 b$ & $73.5 e$ & $61.5 b$ & $105.2 e$ \\
\hline \multicolumn{5}{|l|}{ ET } \\
\hline $\mathrm{C}$ & $58.9 b$ & $58.9 b$ & $64.8 b$ & $183.8 d$ \\
\hline St & $65.1 e$ & $89.2 d$ & $91.7 d$ & $186.9 d$ \\
\hline
\end{tabular}

\section{Duration of the Grain Filling Period and the Weight of $T G W$}

The grain filling period was shorter in water-St plants (48 days) than in water-C plants (55 days). AVG and Benz treatments prolonged the grain filling period (62 days). TGW was subsequently affected by duration with values about $50 \%$ higher in water-C compared with water-St plants. AVG and Benz treatment produced ears with significantly heavier grains than water or ET treat- 


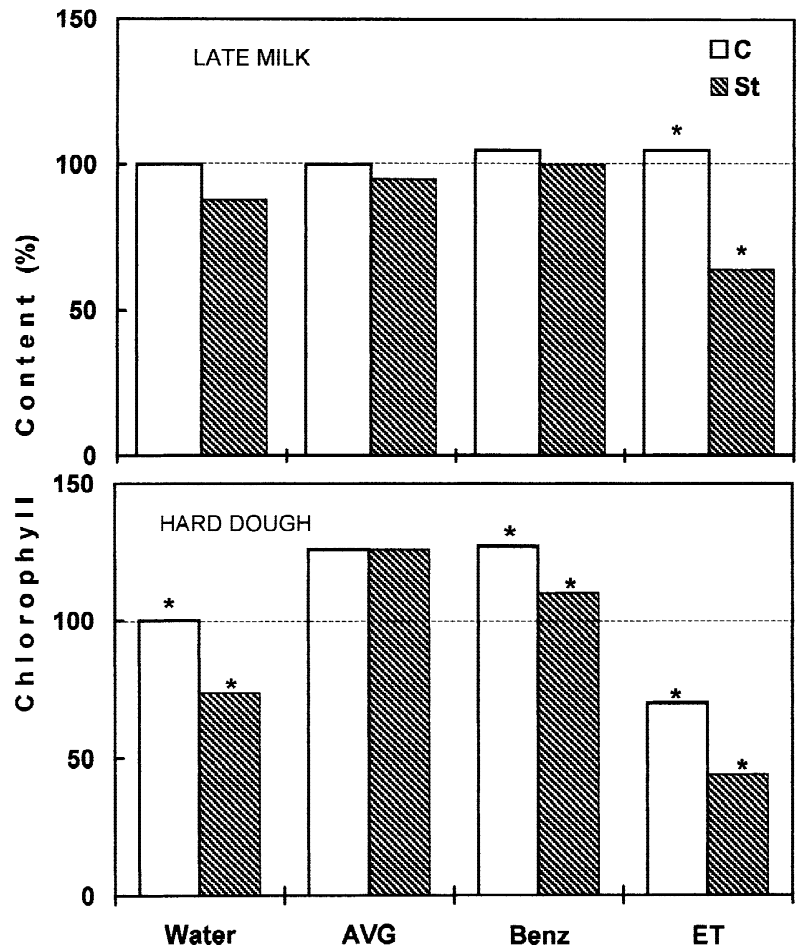

Fig. 1. Effect of $50 \mu \mathrm{M} \mathrm{AVG}, 1 \mathrm{~mm}$ Benz, and $50 \mathrm{~mm}$ ET, sprayed at postanthesis, on the chlorophyll content of flag leaves (expressed as a percentage of water-C), at late milk and hard dough 1 stages of wheat plants. Columns marked with $(*)$ within the same treatment are significant at $p=0.05$.

ment. Plants sprayed with ET produced the smallest and lightest grains in all treatments. On the other hand, Rw plants produced heavier grains than those produced by $\mathrm{St}$ plants (Table 3 ).

\section{Total Protein in Grains}

Application of AVG, Benz, or ET increased the content of protein in their grains compared with the water-C $(12.36,11.23,10.12$, and $9.05 \%$, respectively). St plants produced, in all treatments, grains with more proteins compared with $\mathrm{C}$.

If the stress was reversed by rewatering ( $\mathrm{Rw})$, the total protein content in grains was lower than in St plants but higher than that of the $\mathrm{C}$ plants (Table 4).

\section{Discussion}

The loss of chlorophyll and the leakage of cell solutes, used as markers of senescence in green tissues, indicated that these processes were hastened in wheat by water stress, as reported previously (Baisak et al. 1994, Beltrano et al. 1994, Thomas and Stoddart 1980).

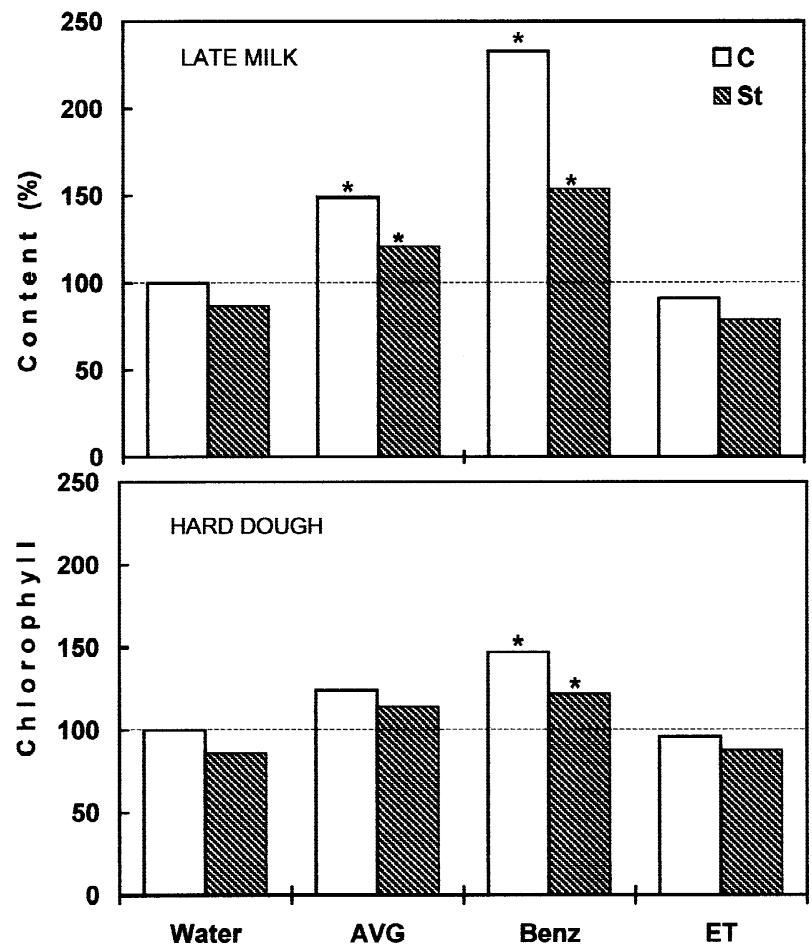

Fig. 2. Effect of $50 \mu \mathrm{M} \mathrm{AVG}, 1 \mathrm{~mm}$ Benz, and $50 \mathrm{~mm}$ ET, sprayed at postanthesis, on the chlorophyll content of ears (expressed as a percentage of water-C), at late milk and hard dough 1 stages of wheat plants. Columns with marked (*) within the same treatment are significant at $p=0.05$.

Table 3. Effect of $50 \mu \mathrm{M}$ AVG, $1 \mathrm{~mm}$ Benz, and $50 \mathrm{~mm}$ ET, sprayed at postanthesis, on TWG of wheat plants subjected to different treatments at soft dough stage. Data within columns accompanied by the same letter are not significantly different at $p=0.05$.

\begin{tabular}{llll}
\hline \multirow{2}{*}{ Treatment } & \multicolumn{4}{l}{ Thousand grain weight $(\mathrm{g})$} \\
\cline { 2 - 4 } & $\mathrm{C}$ & $\mathrm{St}$ & $\mathrm{RW}$ \\
\hline Water & $34.80 b$ & $23.03 b$ & $33.31 b$ \\
AVG & $37.90 c$ & $35.50 c$ & $40.79 c$ \\
Benz & $35.76 c$ & $32.12 c$ & $34.29 b$ \\
ET & $18.17 a$ & $18.18 a$ & $19.18 a$ \\
\hline
\end{tabular}

Flag leaves increased ethylene production under water deficit from the late milk to hard dough 3 stage, which suggests that this hormone accelerated ear senescence and grain maturity. Likewise, as expected, AVG inhibited its evolution, but ET had an opposite effect (Beltrano et al. 1994, Labraña et al. 1991). In accordance with Baker et al. (1977), who found that Benz prolongs the life span of carnation, it was determined that in wheat this substance decreased ethylene production, and therefore, it prolongs the ear filling period.

AVG-C and Benz-C plants not only diminished ethylene production by flag leaves and ears but also main- 
Table 4. Effect of $50 \mathrm{~mm} \mathrm{AVG,} 1 \mathrm{~mm}$ Benz, and $50 \mathrm{~mm}$ ET, sprayed at postanthesis, on protein content at maturity of wheat plants subjected to different treatments at soft dough stage. Data within columns accompanied by the same letter are not significantly different at $p=$ 0.05 .

\begin{tabular}{llll}
\hline \multirow{2}{*}{ Treatment } & \multicolumn{3}{l}{ Total protein $(\% \mathrm{DW})$} \\
\cline { 2 - 4 } & $\mathrm{C}$ & $\mathrm{St}$ & $\mathrm{Rw}$ \\
\hline Water & $9.05 a$ & $12.53 a$ & $11.02 a$ \\
AVG & $12.36 c$ & $16.26 b$ & $14.74 b$ \\
Benz & $11.23 b$ & $15.12 b$ & $13.82 b$ \\
ET & $10.12 a$ & $11.45 a$ & $10.41 a$ \\
\hline
\end{tabular}

tained chlorophyll content. Consequently, premature senescence of ears was prevented, as found previously by Beltrano et al. (1994).

Likewise, when plants were under stress, AVG and Benz produced a diminution of ethylene production by flag leaves and ears and maintained the chlorophyll content. In agreement with other authors (Droillard et al. 1987, Mayak et al. 1983, Paulin et al. 1986, Sylvestre et al. 1989), it was reasonable to think that the free radicals, induced by desiccation, and the parallel acceleration of ethylene synthesis hastened the senescence process of flag leaves and ears. This possibility was supported by the fact that both Benz (scavenging free radicals) and AVG (inhibiting ethylene synthesis), reversed the effect of drought, delaying plant senescence (Beltrano et al. 1997).

It is interesting that the inhibition of ethylene synthesis by AVG and the hindrance of free radicals by the scavenger Benz prolonged the grain filling period. As can be seen in Table 3, the effect of dehydration on TGW was also reversed by rewatering. On the other hand, not only AVG but also Benz attenuated the differences of the stress on the TGW.

It has been noticed that drought increased the total grain protein, which was not reversed by rewatering. Furthermore, the treatment with AVG or Benz in all cases augmented the protein content above the control. This effect could be explained by the fact that grain filling is influenced considerably by the environment. Under water stress, the deposition of starch is more sensitive than the deposition of protein. An increase in the percentage of grain protein may occur without an increase in protein content per se (Brooks et al. 1982, Morgan and Riggs 1981).

Empirically, the grain response to developing water stress is similar to the response to elevated temperature. Elevated temperature $\left(>30^{\circ} \mathrm{C}\right)$ in postanthesis may cause premature cessation of starch deposition in the endosperm. In contrast, the accumulation of the protein appears largely unaffected, so an increase in the percentage of grain protein may result (Bhullar and Jenner 1985, Chowdhury and Wardlaw 1978, Jenner et al. 1991).
In the field, protein and starch deposition during the grain filling period do not always appear simultaneously; the rate of protein accumulation may reach its peak before that of starch, and it may decline earlier (Herzog and Stamp 1983). This difference in the patterns of deposition has been used to explain a higher percentage of grain protein under environmental conditions that shorten the duration of the grain filling period.

Although in all treatments the water deficit modified the normal levels of scavengers and free radicals, adequate water potential restored them (Beltrano et al. 1997). In addition, it was reasonable to assume that the rewatering, after a short water stress, could reestablish the cellular homeostasis.

The present results demonstrate that senescence can be deferred by AVG, inhibiting the ethylene synthesis, or by Benz, blocking the action of free radicals.

Senescence is an active programmed phenomenon, yet it could be accelerated by exogenous factors (Brooks et al. 1982, Caldwell and Whitman 1987, Kramer 1983, Mayak et al. 1983). In wheat ears senescence is triggered after anthesis. Nevertheless, the speed of this ineluctable phenomenon can be regulated by environmental factors such as water availability.

Acknowledgments. We thank Prof. José Luis Araus for critical reading, Ofelia Ocampo and Olga Peluso for technical assistance, and Consejo Nacional de Investigaciones Cientificas y Técnicas (CONICET), Argentina, for financial support. M. Ronco and J. Beltrano are researchers of CIC-BA.

\section{References}

Baisak R, Dharanidhar R, Patel BBA, Manoranjan K (1994) Alteration in the activities of active oxygen-scavenging enzymes of wheat leaves subjected to water stress. Plant Cell Physiol 35:489-495

Baker JE, Wang CY, Leiberman M, Hardendurg R (1977) Delayed senescence in carnations by a rhizobitoxine analog and sodium benzoate. HortScience 12:38-39

Beltrano J, Bártoli C, Montaldi ER, Carbone A (1997) Emission of water stress ethylene in wheat (Triticum aestivum L.) ears: Effects of rewatering. Plant Growth Reg 21:121-126

Beltrano J, Carbone A, Montaldi ER, Guiamet JJ (1994) Ethylene as promoter of wheat grain maturation and ear senescence. Plant Growth Reg 15:107-112

Bhullar SS, Jenner CF (1985) Differential responses to high temperatures of starch and nitrogen accumulation in the grain of four cultivars of wheat. Aust J Plant Physiol 12:363-375

Bradford KL, Hsiao TC (1982) Physiological responses to moderate water stress. In: Lange OL, Nobel PS, Osmond CB, Ziegler H (eds Encyclopedia of plant physiology (new series) 12B: Physiological plant ecology. II. Water relations and carbon assimilation Springer-Verlag, Berlin pp. 263-324

Bray EA (1993) Molecular responses to water deficit. Plant Physiol 103:1035-1040

Brooks A, Jenner CF, Aspinall D (1982) Effects of water deficit on endosperm starch granules and grain physiology of wheat and barley. Aust J Plant Physiol 9:423-436 
Caldwell CR, Whitman CE (1987) Temperature-induced protein conformational changes in barley root plasma membrane-enriched microsomes. I. Effect of temperature on membrane protein and lipid mobility. Plant Physiol 84:918-923

Chowdhury SI, Wardlaw IF (1978) The effect of temperature on kernel development in cereals. Aust J Agric Res 29:205-223

Cuello R, Lahora A (1993) Chlorophyll degradation by free radicals derived from linolenic acid in incubated barley thylacoids. Acta Bot Neerl 42:481-490

Droillard MJ, Paulin A, Massot JC (1987) Free radical production, catalase and superoxide dismutase activities, and membrane integrity during senescence of petals of cut carnation (Dianthus caryphyllus). Physiol Plant 71:197-202

Elstner EF (1982) Oxygen activation and oxygen toxicity. Annu Rev Plant Physiol 33:73-96

Hendry GAF, Houghton JD, Brown SB (1987) The degradation of chlorophyll: A biological enigma. New Phytol 107:255-302

Herzog H, Stamp P (1983) Dry matter and nitrogen accumulation in grain at different ear positions in "Gigas" semidwarf and normal spring wheat. Euphytica 32:511-520

Hoagland DR, Arnon DI (1950) The water-culture method for growing plants without soil. Circular 347. California Agric Exp St, College of Agriculture, University of California, Berkely

Jenner CF, Ugande ED, Aspinall D (1991) The physiology of starch and protein deposition in the endosperm of wheat. Aust J Plant Physiol 18:211-216

Jones HG, Corlett JE (19920 Current topics in drought physiology: Review. J Agric Sci 119:291-296

Kramer PJ (1983) Water relations in plants. Academic Press, New York

Labraña X, Vendrel M, Araus JL (1991) Ethylene production in wheat flag leaves and ears during grain filling. Plant Physiol Biochem 29:349-354

Levitt J (1980) Responses of plants to environmental stresses. Vol II. Water, radiation, salt and others. Academic Press, New York, pp 25-211

Mayak S, Legge RL, Thompson JE (1983) Superoxide radical production by microsomal membranes from senescing carnation flowers: An effect of membrane fluidity. Phytochemistry 22:13751380

Morgan AG, Riggs TJ (1981) Effects of drought on yield and on grain and malt characters in spring barley. J Sci Food Agric 32:339346

Navari-Izzo F, Quartacci MF, Melfi D, Izzo R (1993) Lipid composition of plasma membranes isolated from sunflower seedlings grown under water stress. Physiol Plant 87:508-514

Noodén CD, Guiamet JJ (1996) Genetic control of senescence and aging in plants. In: Schnieder EL, Rowe JW (eds) Handbook of the biology of aging. Academic Press, FL, pp 94-118

Paulin A, Droillard NJ, Bureau JM (1986) Effect of a free radical scavenger, 3,4,5-trichlorophenol, on ethylene production and on changes in lipids and membrane integrity during senescence of petals of cut carnations (Dianthus caryophyllus). Physiol Plant 67:465-471

Quartacci MF, Navari-Izzo F (1992) Water stress and free radicalmediated changes in sunflower seedlings. J Plant Physiol 139: $621-625$

Senaratna T, McKesie BD, Stinson AN (1985) Simulation of dehydration injury to membranes from soybean axes by free radicals. Plant Physiol 77:472-474

Sholander PF, Hammel HT, Bradstreet DE, Hemmigsen EA (1965) Sap pressure in vascular plants. Science 148:339-346

Smirnoff N (1993) The role of active oxygen in the response of plants to water deficit and desiccation. New Phytol 125:27-58

Sylvestre I, Droillard, MJ, Bureau JM, Paulin A (1989) Effect of the ethylene rise on the peroxidation of membrane lipids during the senescence of cut carnation. Plant Physiol Biochem 27:407-413

Thimann KV (1982) The senescence of leaves. In: Thimann KV (ed) Senescence in plants. CRC Press, Boca Raton, FL pp. 86-115

Thomas H, Stoddart JL (1980) Leaf senescence. Annu Rev Plant Physiol 31:83-111

Turner NC (1986) Crop water deficit: A decade of progress. Adv Agric $39: 1-51$

Winston GW (1990) Physiochemical basis for free radical formation in cells: Production and defenses. In: Alsches RG, Cumming JR (eds) Stress responses in plants: Adaptation and acclimation mechanisms. Wiley-Liss Inc., New York, pp 57-86

Zadocks JC, Chang TT, Konzak CF (1974) A decimal code for the growth stages of cereals. Weed Res 14:415-421

Zscheile FP, Comar CL (1941) Influence of preparative procedure on the purity of chlorophyll components shown by absorption spectra. Bot Gaz 102:463-481 